\title{
Lysobacter capsici sp. nov., with antimicrobial activity, isolated from the rhizosphere of pepper, and emended description of the genus Lysobacter
}

Correspondence Young Ryun Chung yrchung@gnu.ac.kr

\author{
Joo Hwang Park, Rumi Kim, Zubair Aslam, Che Ok Jeon \\ and Young Ryun Chung
}

\author{
Division of Applied Life Science (BK 21), PMBBRC and EB-NCRC, Gyeongsang National \\ University, Jinju 660-701, Republic of Korea
}

\begin{abstract}
The taxonomic position of a novel bacterial strain, YC5194 ${ }^{\top}$, with antimicrobial activity, isolated from the rhizosphere of pepper in Jinju, South Korea, was studied using a polyphasic approach. Cells of the strain were Gram-negative, rod-shaped, facultative anaerobes. It grew at a temperature of $15-37{ }^{\circ} \mathrm{C}$ (optimum $28^{\circ} \mathrm{C}$ ). Growth of the strain occurred between $\mathrm{pH} 5.5$ and 8.5, with an optimum of $\mathrm{pH}$ 7.0-7.5. The strain inhibited mycelial growth of Pythium ultimum, Colletotrichum gloeosporioides, Fusarium oxysporum, Botrytis cinerea, Rhizoctonia solani and Botryosphaeria dothidea and growth of Bacillus subtilis. The $\mathrm{G}+\mathrm{C}$ content of the total DNA was $65.4 \mathrm{~mol} \%$. The $16 \mathrm{~S}$ rRNA gene sequence of the strain was most closely related to species of the genus Lysobacter ( $<94.0$ to $>99.0 \%$ sequence similarity). Chemotaxonomic data (major quinone, Q-8; major polar lipids, diphosphatidylglycerol, phosphatidylethanolamine, phosphatidylglycerol and phosphatidyl- $N$-methylethanolamine; major fatty acids, iso- $\mathrm{C}_{15: 0 \text {, }}$ summed feature $3, C_{16: 0}$, iso- $C_{17: 1} \omega 9 c$ and $\left.C_{18: 1} \omega 7 c\right)$ supported the affiliation of strain YC5194 ${ }^{\top}$ to the genus Lysobacter. Phylogenetic analysis based on $16 \mathrm{~S}$ rRNA gene sequences, DNA-DNA hybridization data and biochemical and physiological characteristics strongly supported the genotypic and phenotypic differentiation of strain YC5194 ${ }^{\top}$ from species of Lysobacter with validly published names. Strain YC5194 ${ }^{\top}$ therefore represents a novel species, for which the name Lysobacter capsici sp. nov. is proposed. The type strain is YC5194 ${ }^{\top}$ (=KCTC $22007^{\top}=$ DSM $19286^{\top}$ ).
\end{abstract}

The genus Lysobacter is grouped in the family Xanthomonadaceae, belonging to the Gammaproteobacteria. Lysobacter species are typically found in soil and water habitats and are defined by characteristics that include gliding motility, a high $\mathrm{G}+\mathrm{C}$ content and lytic activity against other micro-organisms, including fungi and nematodes (Christensen \& Cook, 1978). The initial description for the genus Lysobacter reported in the 1970s was based primarily on phenotypic characteristics; recently, the genus Lysobacter has been recognized in the phylum Proteobacteria with the help of polyphasic taxonomy (Lee et al., 2006; Weon et al., 2006; Yassin et al., 2007).

Some Lysobacter strains have been reported to have antifungal and antimicrobial activities. Lysobacter sp. XL1

The GenBank/EMBL/DDBJ accession number for the $16 \mathrm{~S}$ rRNA gene sequence of strain $\mathrm{YC5} 194^{\top}$ is EF488749.

Transmission electron micrographs of cells of strain YC5194 ${ }^{\top}$, TLC of polar lipids of two related type strains, fatty acid profiles and API ZYM results for strain YC5194 ${ }^{\top}$ and related type strains and a detailed antimicrobial spectrum for strain $\mathrm{YC} 194^{\top}$ are available as supplementary material with the online version of this paper. produces lysoamidase, from which a drug is derived that is used in the treatment of external infections caused by pathogenic Gram-positive bacteria. It is also effective against many yeast and fungi groups (Ryazanova et al., 2005). Lysobacter enzymogenes was shown to be a potential biocontrol agent for plant fungal pathogens (Folman et al., 2004; Kilic-Ekici \& Yuen, 2003). Lysobacter sp. SB-K88, previously known as a Stenotrophomonas strain (Nakayama et al., 1999), produces three antifungal compounds, xanthobaccins A, B and C; xanthobaccin A suppresses the sugar beet damping-off disease (Islam et al., 2005). Some Lysobacter isolates had strong antibiotic activity against Gram-positive bacteria, especially meticillin-resistant Staphylococcus aureus (Ahmed et al., 2003; Chohnan et al., 2002; Hashizume et al., 2001, 2004; Kato et al., 1998).

Strain YC5194 ${ }^{\mathrm{T}}$ was identified on the basis of $16 \mathrm{~S}$ rRNA gene sequences, DNA-DNA hybridization data and other chemotaxonomic and genotypic characteristics as belonging to a novel species in the genus Lysobacter.

In the process of screening biological control agents for plant-pathogenic fungi, especially those active against 
Pythium ultimum and Colletotrichum gloeosporioides, soil samples were collected from the rhizosphere of pepper (Capsicum annuum L.) in Jinju, Korea, in July 2003. Ten grams of each soil sample was serially diluted in $100 \mathrm{ml}$ distilled deionized water. Plates containing $2 \%$ tryptic soy agar (2\% TSA; Difco) ( $\mathrm{pH} \mathrm{7.2)} \mathrm{were} \mathrm{inoculated} \mathrm{with}$ $0.1 \mathrm{ml}$ aliquots and incubated at $28{ }^{\circ} \mathrm{C}$ for 3 days. Only bacterial strains with antifungal or antibacterial activity were selected (Chung et al., 1999, 2000). The details of fungal, yeast and bacterial strains used to check antimicrobial activity are given in Supplementary Table S3 (available in IJSEM Online). Strain YC5194 ${ }^{\mathrm{T}}$, with a broad antifungal spectrum, was further investigated for its taxonomic position because the 16S rRNA gene sequence of the strain was most closely related to those of species of the genus Lysobacter ( $<94.0$ to $>99.0 \%$ sequence similarity).

Cell morphology was observed under a Nikon light microscope at $\times 1000$ magnification and by using a transmission electron microscope (Hitachi H-600) with cells grown for 1 day at $28{ }^{\circ} \mathrm{C}$ on $2 \%$ TSA. Catalase and oxidase tests were performed by the procedures outlined by Cappuccino \& Sherman (2002). Carbohydrate assimilation and enzyme activities were determined by using API ID $32 \mathrm{E}$ and API ID32 STREP at $30{ }^{\circ} \mathrm{C}$ and API ZYM at $37{ }^{\circ} \mathrm{C}$ according to the instructions of the manufacturer (bioMerieux). Growth at different temperatures $(4,15$, 20, 28, 37 and $45{ }^{\circ} \mathrm{C}$ ) was tested on $2 \%$ TSA. Anaerobic growth was tested at $28{ }^{\circ} \mathrm{C}$ by pouring a thick layer of vaspar (50\% petrolatum, $50 \%$ paraffin) on the surface of inoculated $2 \%$ TSA in $35 \mathrm{ml}$ screw-capped glass tubes (Costilow, 1981). Degradation of chitin, starch, gelatin and Tween 20 was investigated by using the protocols outlined by Atlas (1993). Growth at different temperatures and $\mathrm{pH}$ was assessed after 3 days incubation. Salt tolerance was tested in $2 \%$ TSA broth medium supplemented with 1$10 \%(\mathrm{w} / \mathrm{v}) \mathrm{NaCl}$ after 7 days incubation. Duplicate antibiotic-sensitivity tests were done using filter-paper discs containing the following: tetracycline, kanamycin, ampicillin (Sigma) and rifampicin, each at concentrations of 10,50 and $100 \mu \mathrm{g} \mathrm{ml}^{-1}$. Discs were placed on $2 \%$ TSA plates that had been spread with strain $\mathrm{YC} 194^{\mathrm{T}}$ or reference strains and the plates were then incubated at $28{ }^{\circ} \mathrm{C}$ for 3 days. Almost all tests were also performed with reference strains Lysobacter gummosus KCTC $12132^{\mathrm{T}}$, Lysobacter antibioticus KCTC $12129^{\mathrm{T}}$, Lysobacter enzymogenes KCTC $12131^{\mathrm{T}}$, Lysobacter koreensis KCTC $12204^{\mathrm{T}}$, Lysobacter daejeonensis DSM $17634^{\mathrm{T}}$ and Lysobacter yangpyeongensis DSM $17635^{\mathrm{T}}$.

Extraction of genomic DNA was done using a commercial genomic DNA extraction kit (Core Biosystem). The $16 \mathrm{~S}$ rRNA gene of strain YC5194 ${ }^{\mathrm{T}}$ was PCR-amplified from a small amount of purified genomic DNA by using primers 27F and 1492R (Lane, 1991). The PCR product obtained was purified and sequenced according to Chung et al. (1999). 16S rRNA gene sequence was compiled using SeqMan software (DNASTAR) and the sequences of related taxa were obtained from the GenBank database. Multiple alignments were performed by CLUSTAL_x (Thompson et al., 1997) and gaps were edited in the BioEdit program (Hall, 1999). Evolutionary distances were calculated using Kimura's two-parameter model (Kimura, 1983). Phylogenetic trees were constructed by using neighbour-joining (Saitou \& Nei, 1987) and maximum-parsimony (Fitch, 1971) methods in the MEGA3 program (Kumar et al., 2004) with bootstrap values based on 1000 replications (Felsenstein, 1985).

For the measurement of $\mathrm{G}+\mathrm{C}$ content of the chromosomal DNA, genomic DNA of strain YC5194 $4^{\mathrm{T}}$ was extracted and purified as described by Ausubel et al. (1995). DNA was then enzymically degraded into nucleosides and the $\mathrm{G}+\mathrm{C}$ content was determined as described by Mesbah et al. (1989) using reversed-phase HPLC. Cellular fatty acids were analysed using Lysobacter strains grown on TSA for 2 days at $28{ }^{\circ} \mathrm{C}$. Cellular fatty acids were saponified, methylated and extracted according to the protocol of the Sherlock Microbial Identification System version 4.0 software (MIDI). Fatty acids analysed by GC (Hewlett Packard 6890) were identified using the Microbial Identification software package (Khan et al., 1996). The quinone system and polar lipids were determined by TLC, as described by Lechevalier et al. (1977) and Tindall (1990).

DNA-DNA hybridization was carried out to evaluate the genomic DNA relatedness between strain $\mathrm{YC} 194^{\mathrm{T}}$ and those Lysobacter strains that had high $16 \mathrm{~S}$ rRNA gene sequence similarity $(>97.0 \%)$ to strain $\mathrm{YC} 5194^{\mathrm{T}}$ (Stackebrandt \& Goebel, 1994; Wayne et al., 1987). Extracted genomic DNA was fragmented with HaelII for slot hybridization. Digested DNAs were diluted serially and loaded into slots with three replications for each sample and DNAs were used individually as labelled probes for cross-hybridization. Randomly primed DNA labelling with digoxigenin-dUTP and hybridization (hybridization temperature, $53{ }^{\circ} \mathrm{C}$; washing temperature, $65-68{ }^{\circ} \mathrm{C}$ ) were performed using a DIG High Prime DNA labelling kit (Roche Applied Science) according to the manufacturer's instructions and standard procedures (Lim et al., 2005; Sambrook \& Russell, 2001). The signals of the dilution series were quantified using Bio-Rad GelDoc scanning software. The signals produced by self-hybridization were inferred as $100 \%$, and hybridization values (\%) were calculated from the results of three experiments.

The novel strain was Gram-negative and non-motile and had gliding activity. Cells were rod-shaped $(0.3-0.5 \times 2.0$ $20 \mu \mathrm{m})$ and occurred singly and in pairs and irregular filament-like forms (Supplementary Fig. S1). Colonies grown on $2 \%$ TSA plates for 3 days were smooth, circular and creamy white to yellow, $2-4 \mathrm{~mm}$ in diameter, and they changed form as they grew older due to motility. Fruiting bodies were not observed. Growth was facultatively anaerobic. Only strain YC5194 ${ }^{\mathrm{T}}$ of seven tested Lysobacter strains had $\alpha$-galactosidase activity. Physiological characteristics of strain $\mathrm{YC} 194^{\mathrm{T}}$ are summarized in the species 
Table 1. Differential phenotypic characteristics between strain YC5194 ${ }^{\top}$ and related Lysobacter type strains

Strains: 1, YC5194 ${ }^{\mathrm{T}}$ (L. capsici sp. nov.); 2, L. gummosus KCTC $12132^{\mathrm{T}}$; 3, L. antibioticus KCTC 12129 ${ }^{\mathrm{T}}$; 4, L. enzymogenes KCTC $12131^{\mathrm{T}}$; 5 , L. koreensis KCTC $12204^{\mathrm{T}} ; 6$, L. daejeonensis DSM $17634^{\mathrm{T}} ; 7$, L. yangpyeongensis DSM $17635^{\mathrm{T}}$. All data were obtained in this study unless indicated. + , Positive; -, negative; \pm , weak; ND, not determined; EMB, eosin methylene blue. All of the strains were able to hydrolyse casein, gelatin and Tween 20 but not agar or urea and all strains showed optimal growth in the absence of $\mathrm{NaCl}$.

\begin{tabular}{|c|c|c|c|c|c|c|c|}
\hline Characteristic & 1 & 2 & 3 & 4 & 5 & 6 & 7 \\
\hline Cell size $(\mu \mathrm{m})$ & $0.3-0.5 \times 2.0-20$ & $0.4 \times 2.0$ & $0.4 \times 6.5$ & $0.5 \times 38.0$ & $0.5-0.8 \times 1.5-2.0$ & $0.4-0.6 \times 3.0-4.0$ & $0.4-0.6 \times 3.0-4.0$ \\
\hline Colony type & Smooth & Smooth & Mucoid & Smooth & Smooth & Smooth & Smooth \\
\hline \multicolumn{8}{|c|}{$\mathrm{NaCl}$ concentration for growth $(\% \mathrm{w} / \mathrm{v})$} \\
\hline Range & $0-2$ & $0-2$ & $0-1$ & $0-1$ & $0-2$ & $0-3$ & $0-1$ \\
\hline No growth & 3 & $3^{a_{\dagger}}$ & $3^{a}$ & $3^{a}$ & $3^{b}$ & ND & ND \\
\hline Oxidase & + & + & + & + & - & + & + \\
\hline$\alpha$-Galactosidase & + & - & - & - & - & - & - \\
\hline Trypsin & + & - & - & + & - & + & + \\
\hline$\alpha$-Glucosidase & + & - & - & + & - & + & + \\
\hline$N$-Acetyl- $\beta$-glucosaminidase & - & + & + & - & - & - & + \\
\hline \multicolumn{8}{|l|}{ Hydrolysis of: } \\
\hline \multicolumn{8}{|l|}{ Growth on/at: } \\
\hline Citrate & + & + & + & + & + & - & - \\
\hline D-Glucose & - & + & - & + & - & + & - \\
\hline Arabinose & - & + & - & - & + & - & - \\
\hline Maltose & - & + & + & + & - & + & - \\
\hline $\mathrm{pH} 4$ & - & + & - & \pm & $\mathrm{ND}$ & - & - \\
\hline $\mathrm{pH} 10$ & - & - & - & + & ND & - & - \\
\hline MacConkey agar & - & - & - & + & - & - & - \\
\hline EMB agarł & $+(\mathrm{Po})$ & $+(\mathrm{Pi})$ & $+(\mathrm{Pi})$ & $+(\mathrm{Pi})$ & $+(\mathrm{Pi})$ & - & - \\
\hline $\mathrm{G}+\mathrm{C}$ content $(\mathrm{mol} \%)$ & 65.4 & $65.7^{a}$ & $69.2^{a}$ & $69.0^{a}$ & $68.9^{b}$ & $61.7^{c}$ & $67.3^{c}$ \\
\hline
\end{tabular}

${ }^{*} \mathrm{C}$, Cream-coloured; DY, deep yellow; G, green; PY, pale yellow; Y, yellow.

$\dagger$ Data taken from other studies as indicated: $a$, Christensen \& Cook (1978); b, Lee et al. (2006); c, Weon et al. (2006).

\$Colour of growth indicated as: Pi, pink; Po, pinkish-orange.

description and a comparison of selective characteristics with related type strains is shown in Table 1.

The cellular fatty acid profiles of strain $\mathrm{YC} 194^{\mathrm{T}}$ and related Lysobacter type strains are shown in Supplementary Table S1. The major cellular fatty acids in strain YC5194 included iso- $\mathrm{C}_{15: 0}(23.3 \%)$, summed feature $3(20.4 \%)$, $\mathrm{C}_{16: 0}(10.8 \%)$, iso- $\mathrm{C}_{17: 1} \omega 9 c(9.3 \%), \mathrm{C}_{18: 1} \omega 7 c(6.5 \%)$, iso- $\mathrm{C}_{11: 0} \quad 3-\mathrm{OH} \quad(3.8 \%)$, iso- $\mathrm{C}_{17: 0} \quad(3.7 \%)$, iso- $\mathrm{C}_{11: 0}$ $(2.3 \%), \mathrm{C}_{16: 1} \omega 11 c(2.2 \%), \mathrm{C}_{14: 0}(1.9 \%), \mathrm{C}_{15: 0}(1.7 \%)$ and trace amounts $(<1.0 \%)$ of some other fatty acids were detected, which are shown in Supplementary Table S1. Although the major fatty acids were similar to those of other members of the genus Lysobacter, significant differences were found between different species in the genus and the novel strain. $\mathrm{C}_{9: 0}$ and $\mathrm{C}_{16: 1} \omega 11 c(2.2 \%)$ were detected only in strain YC5194 ${ }^{\mathrm{T}}$ (Supplementary Table S1). The following polar lipids are present: diphosphatidylglycerol, phosphatidylethanolamine, phosphatidylglycerol and phosphatidyl- $N$-methylethanolamine. An unknown polar lipid AL1 (amino group-containing lipid) was also detected (Fig. 1). The polar lipids of two closely related type strains, $L$. gummosus KCTC $12132^{\mathrm{T}}$ and L. antibioticus KCTC $12129^{\mathrm{T}}$, were also determined. The major polar lipids were the same, but the unknown amino group-containing lipids differed from species to species (Fig. 1 and Supplementary Fig. S2).

Strain YC5194 ${ }^{\mathrm{T}}$ inhibited growth of the fungi Botrytis cinerea, Botryosphaeria dothidea, Colletotrichum gloeosporioides, Fusarium oxysporum, Pythium ultimum, Rhizoctonia solani, Sclerotinia sclerotiorum and Aspergillus fumigatus, the yeast Candida albicans and yeast-like Cryptococcus neoformans and the Gram-positive bacterium Bacillus subtilis. It has particularly strong inhibition activity against Colletotrichum gloeosporioides, Colletotrichum coccodes, Colletotrichum orbiculare and Pythium ultimum 


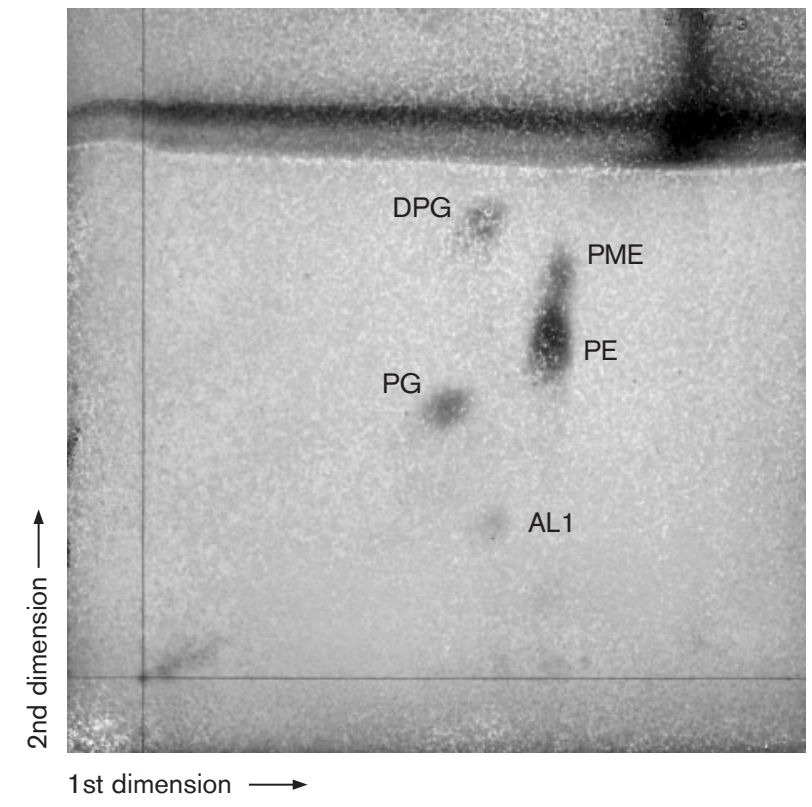

Fig. 1. Two-dimensional TLC of polar lipids from strain YC5194 ${ }^{\top}$. Ascending solvent system: 1st dimension, chloroform/methanol/ water ( $65: 25: 4$, by vol.); 2nd dimension, chloroform/acetic acid/ methanol/water ( $80: 13: 10: 1.6$, by vol.). For detection of polar lipids, molybdatophosphoric acid [for phosphatidylethanolamine (PE), phosphatidyl- $N$-methylethanolamine (PME), phosphatidylglycerol (PG) and diphosphatidylglycerol (DPG)] was applied. AL1, Unknown amino group-containing lipid.

(Supplementary Table S3). Other reference strains had no inhibitory activity against Pythium ultimum or Colletotrichum gloeosporioides except L. gummosus, which had a weak inhibitory effect on Colletotrichum gloeosporioides (Fig. 2).

The DNA G + C content of strain YC5194 ${ }^{\mathrm{T}}$ was $65.4 \mathrm{~mol} \%$. This value is within the range for the genus Lysobacter (65.4-70.1 mol\%; Christensen \& Cook, 1978). Q-8 was the major quinone in strain $\mathrm{YC} 5194^{\mathrm{T}}$ and in all type strains of recognized Lysobacter species.
The 16S rRNA gene sequence of strain $\mathrm{YC} 194^{\mathrm{T}}$ was a continuous stretch of $1470 \mathrm{bp}$. Sequence similarity calculations after a neighbour-joining analysis indicated that the closest relatives of the novel strain were L. gummosus ATCC $29489^{\mathrm{T}}$ (99.59\% similarity), L. antibioticus DSM $2044^{\mathrm{T}}$ (99.40\%), L. enzymogenes DSM $2043^{\mathrm{T}}$ (97.35\%) and L. koreensis KCTC $12204^{\mathrm{T}}(97.0 \%)$; low levels of similarity $(<97.0 \%)$ were found with other type strains of the genus Lysobacter. Phylogenetic trees based on the neighbourjoining and maximum-parsimony methods (Fig. 3) showed that strain YC5194 ${ }^{\mathrm{T}}$ formed a cluster supported with a high bootstrap value $(100 \%)$.

Strain YC5194 ${ }^{\mathrm{T}}$ exhibited 8, 10, 25 and $40 \%$ DNA-DNA relatedness, respectively, to $L$. koreensis KCTC $12204^{\mathrm{T}}, L$. enzymogenes DSM 2043 ${ }^{\mathrm{T}}$, L. gummosus ATCC $29489^{\mathrm{T}}$ and L. antibioticus DSM $2044^{\mathrm{T}}$. The DNA-DNA relatedness values with $L$. daejeonensis DSM $17634^{\mathrm{T}}$ and L. yangpyeongensis DSM $17635^{\mathrm{T}}$ were below $5 \%$, which showed that strain YC5194 ${ }^{\mathrm{T}}$ belongs to a distinct genomic species (Stackebrandt \& Goebel, 1994; Wayne et al., 1987). According to Fox et al. (1992) and Stackebrandt et al. (2002), 16S rRNA gene sequences, protein-coding gene sequences and DNA-DNA hybridization should be considered as molecular criteria for species delineation. In cases of very high similarity (16S rRNA gene sequences), DNA-DNA hybridization is a more powerful and helpful tool to distinguish strains at the species level.

Thus 16S rRNA gene sequence similarity, phylogenetic analysis, G $+\mathrm{C}$ content, Gram-staining behaviour (Gramnegative), gliding activity and other enzyme activities clearly indicate that strain YC5194 ${ }^{\mathrm{T}}$ belongs to the genus Lysobacter. To the best of our knowledge, this is the first classified member of the genus Lysobacter that has antifungal activity against Pythium ultimum. Strain YC5194 ${ }^{\mathrm{T}}$ also showed different results in antibiotic-sensitivity tests compared with reference strains (L. gummosus KCTC $12132^{\mathrm{T}}$, L. antibioticus KCTC $12129^{\mathrm{T}}$ and L. enzymogenes KCTC $12131^{\mathrm{T}}$ ). Strain $\mathrm{YC} 5194^{\mathrm{T}}$ is positive for chitinase, gelatinase and lipase but negative for hydrolysis of starch, agar and cellulose. Thus, low DNA-DNA relatedness with other Lysobacter species, significant differences in fatty acid profiles (Supplementary
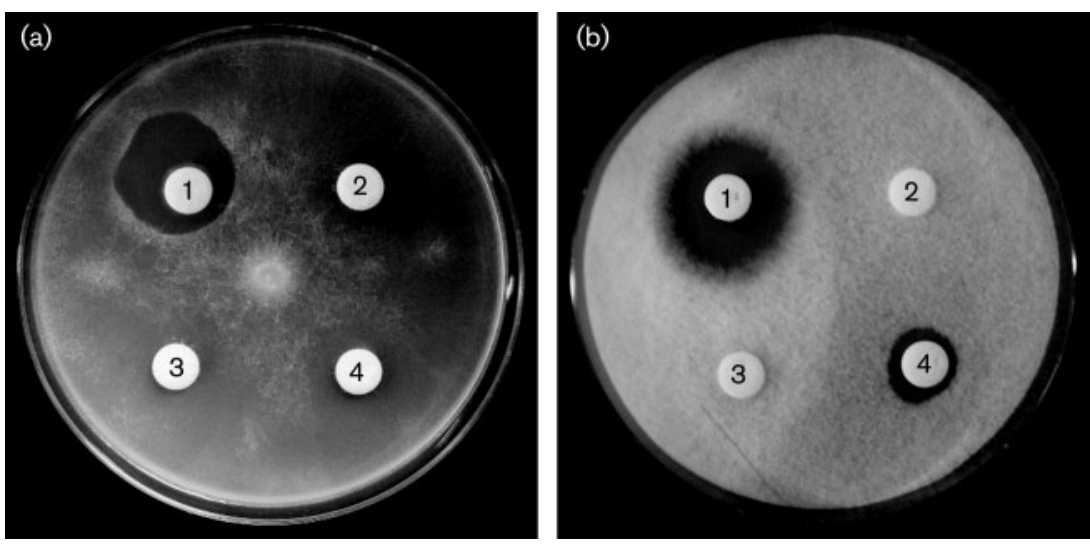

Fig. 2. Effect on mycelial growth of Pythium ultimum (a) and Colletotrichum gloeosporioides (b) of culture filtrates of strain YC5194 ${ }^{\top}$ (1), L. antibioticus KCTC $12129^{\top}$ (2), L. enzymogenes KCTC $12131^{\top}$ (3) and $L$. gummosus KCTC $12132^{\top}$ (4). 


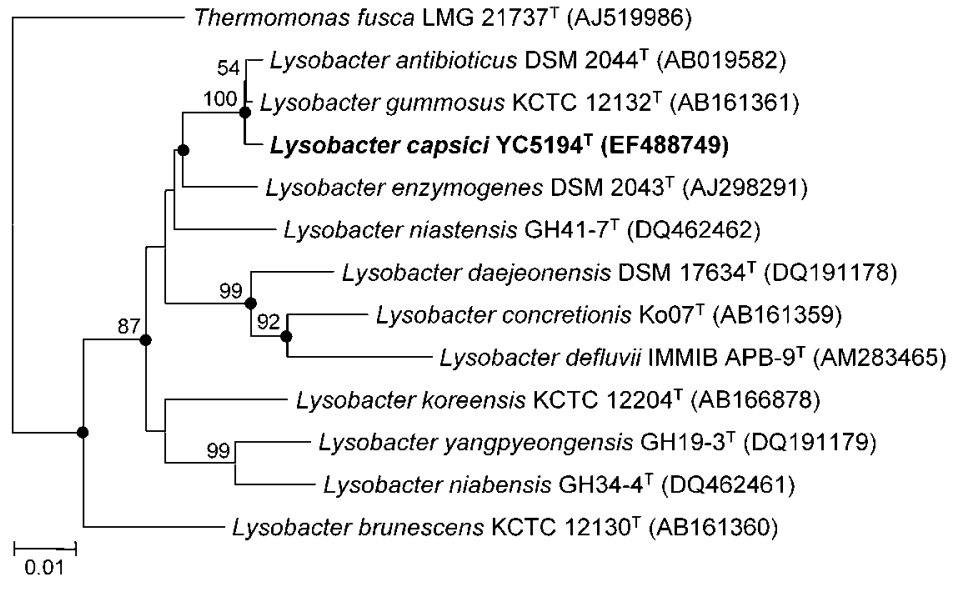

Fig. 3. Phylogenetic tree constructed from comparative analysis of 16S rRNA gene sequences showing the relationships of strain YC5194 ${ }^{\top}$ with other related species. The tree was constructed by using the neighbour-joining method and Jukes and Cantor evolutionary distance matrix data obtained from unambiguously aligned nucleotides. Solid circles indicate that the corresponding clades were also recovered in maximum-parsimony trees. Bootstrap values (expressed as percentages of 1000 replications) greater than $50 \%$ are shown at branch points. Bar, 1 substitution per 100 nucleotide positions.
Table S1), polar lipid differences (Fig. 1 and Supplementary Fig. S2), phylogenetic trees (Fig. 3), antibiotic sensitivities and some physiological and biochemical characteristics (Table 1, Supplementary Table S2 and Supplementary Fig. S2) clearly distinguish strain $\mathrm{YC} 194^{\mathrm{T}}$ as a member of a novel species of the genus Lysobacter, for which the name Lysobacter capsici sp. nov. is proposed.

\section{Emended description of the genus Lysobacter}

Characteristics are the same as given in the original description of the genus Lysobacter (Christensen \& Cook, 1978) with the following amendment. The genus Lysobacter has the following polar lipids: diphosphatidylglycerol, phosphatidylethanolamine, phosphatidylglycerol and phosphatidyl- $N$-methylethanolamine. Some unknown amino group-containing lipids are also present, which may differ from species to species (Fig. 1 and Supplementary Fig. S2).

\section{Description of Lysobacter capsici sp. nov.}

Lysobacter capsici (cap'si.ci. N.L. gen. n. capsici of Capsicum, referring to the isolation of the type strain from the rhizosphere of Capsicum annuum L.).

Cells are Gram-negative, facultatively anaerobic, rodshaped, non-spore-forming and non-motile but having gliding activity, $0.3-0.5 \mu \mathrm{m}$ wide by $2.0-20 \mu \mathrm{m}$ long. Cells occur singly and in pairs and can form irregular filamentlike structures. Colonies grown on $2 \%$ TSA at $30{ }^{\circ} \mathrm{C}$ for 3 days are $2.0-4.0 \mathrm{~mm}$ in diameter, creamy white to yellow, smooth and circular. The temperature range for growth is $15-37{ }^{\circ} \mathrm{C}$ (very weak growth at $4{ }^{\circ} \mathrm{C}$ ); no growth occurs at $45{ }^{\circ} \mathrm{C}$. The optimum temperature for growth is $28{ }^{\circ} \mathrm{C}$. The $\mathrm{pH}$ range for growth is $\mathrm{pH} 5.5-8.5$, with an optimum of $\mathrm{pH} 7.0-7.5$. Growth occurs in the absence of $\mathrm{NaCl}$ and in the presence of 1.0-2.0\%(w/v) $\mathrm{NaCl}$, but not in $3.0 \%(\mathrm{w} / \mathrm{v}) \mathrm{NaCl}$. Sensitive to $10 \mu \mathrm{g}$ rifampicin, $50 \mu \mathrm{g}$ kanamycin and $50 \mu \mathrm{g}$ tetracycline $\mathrm{ml}^{-1}$, but resistant to $100 \mu \mathrm{g}$ ampicillin $\mathrm{ml}^{-1}$. Catalase- and oxidase-positive. Uses 5-bromo-3-indoxyl nonanoate, 4-nitrophenyl $\beta$-Dglucopyranoside and 4-nitrophenyl $\beta$-D-galactopyranoside as sole carbon sources but not the following: L-arabitol, galacturonic acid, potassium 5-ketogluconate, sodium pyruvate, D-mannitol, maltose, adonitol, palatinose, Ltryptophan, 5-bromo-4-chloro-3-indolyl $N$-acetyl- $\beta$-D-glucosaminide, D-glucose, sucrose, L-arabinose, D-arabitol, trehalose, D-rhamnose, inositol, cellobiose and D-sorbitol. Acid is produced from ribose, mannitol, sorbitol, lactose, trehalose, raffinose, glycogen, pullulan, maltose, melibiose, melezitose, methyl $\beta$-D-glucopyranoside and tagatose. Urea is not hydrolysed. Cannot produce acid from sucrose, Larabinose, $\mathrm{D}$-arabitol or cyclodextrin. Tests for $\beta$-glucuronidase and $\beta$-mannosidase are positive. Acetoin is not produced. Enzyme activities for chitinase, alkaline phosphatase, esterase (C-4), esterase lipase (C-8), lipase (C-14), leucine arylamidase, trypsinase, acid phosphatase, naphtholAS-BI-phosphohydrolase, $\alpha$-galactosidase, $\alpha$-glucosidase and $\beta$-glucosidase are present, but valine arylamidase, cystine arylamidase, $\alpha$-chymotrypsin, $\beta$-galactosidase, $\beta$ glucuronidase, $N$-acetyl- $\beta$-glucosaminidase, $\alpha$-mannosidase and $\alpha$-fucosidase activities are absent. Q- 8 is the major quinone. Has the major polar lipids listed in the amended genus description. The DNA G $+\mathrm{C}$ content of the type strain is $65.4 \mathrm{~mol} \%$.

The type strain, YC5194 ${ }^{\mathrm{T}}\left(=\mathrm{KCTC}^{2} 2007^{\mathrm{T}}=\mathrm{DSM} 19286^{\mathrm{T}}\right)$, was isolated from the rhizosphere of pepper in Jinju, Korea.

\section{Acknowledgements}

This work was supported by a Korean Research Foundation grant (KRF-2003-041-F00006), and scholarships for J. H. P. and R. K. were supported by the BK 21 program, Ministry of Education and Human Resources Development, Korea.

\section{References}

Ahmed, K., Chohnan, S., Ohashi, H., Hirata, T., Masaki, T. \& Sakiyama, F. (2003). Purification, bacteriolytic activity, and specificity of $\beta$-lytic protease from Lysobacter sp. IB-9374. J Biosci Bioeng 95, 27-34.

Atlas, R. M. (1993). Handbook of Microbiological Media. Edited by L. C. Parks. Boca Raton, FL: CRC Press. 
Ausubel, F. W., Brent, R., Kingston, R. E., Moore, D. D., Seidman, J. G., Smith, J. A. \& Struhl, K. (1995). Current Protocols in Molecular Biology. New York: Wiley.

Cappuccino, J. G. \& Sherman, N. (2002). Microbiology: a Laboratory Manual, 6th edn. Menlo Park, CA: Benjamin/Cummings.

Chohnan, S., Nonaka, J., Teramoto, K., Taniguchi, K., Kameda, Y., Tamura, H., Kurusu, Y., Norioka, S., Masaki, T. \& Sakiyama, F. (2002). Lysobacter strain with high lysyl endopeptidase production. FEMS Microbiol Lett 213, 13-20.

Christensen, P. \& Cook, F. D. (1978). Lysobacter, a new genus of nonfruiting, gliding bacteria with a high base ratio. Int J Syst Bacteriol 28, 367-393.

Chung, Y. R., Sung, K. C., Mo, H. K., Son, D. Y., Nam, J. S., Chun, J. \& Bae, K. S. (1999). Kitasatospora cheerisanensis sp. nov., a new species of the genus Kitasatospora that produces an antifungal agent. Int J Syst Bacteriol 49, 753-758.

Chung, Y. R., Kim, C. H., Hwang, I. \& Chun, J. (2000). Paenibacillus koreensis sp. nov., a new species that produces an iturin-like antifungal compound. Int J Syst Evol Microbiol 50, 1495-1500.

Costilow, R. N. (1981). Biophysical factors in growth. Manual of Methods for General Bacteriology, pp. 66-78. Edited by P. Gerhardt, R. G. E. Murray, R. N. Costilow, E. W. Nester, W. A. Wood, N. R. Krieg \& G. B. Phillips. Washington, DC: American Society for Microbiology.

Felsenstein, J. (1985). Confidence limits on phylogenies: an approach using the bootstrap. Evolution 39, 783-791.

Fitch, W. M. (1971). Toward defining the course of evolution: minimum change for a specific tree topology. Syst Zool 20, 406-416.

Folman, L. B., De Klein, M. J. E. M., Postma, J. \& van Veen, J. A. (2004). Production of antifungal compounds by Lysobacter enzymogenes isolate 3.1T8 under different conditions in relation to its efficacy as a biocontrol agent of Pythium aphanidermatum in cucumber. Biol Control 31, 145-154.

Fox, G. E., Wisotzkey, J. D. \& Jurtshuk, P., Jr (1992). How close is close: $16 \mathrm{~S}$ rRNA sequence identity may not be sufficient to guarantee species identity. Int J Syst Bacteriol 42, 166-170.

Hall, T. A. (1999). BioEdit: a user-friendly biological sequence alignment editor and analysis program for Windows 95/98/NT. Nucleic Acids Symp Ser 41, 95-98.

Hashizume, H., Igarashi, M., Hattori, S., Hori, M., Hamada, M. \& Takeuchi, T. (2001). Tripropeptins, novel antimicrobial agents produced by Lysobacter sp. J Antibiot (Tokyo) 54, 1054-1059.

Hashizume, H., Hattor, S., Igarashi, M. \& Akamatsu, Y. (2004). Tripropeptin E, a new tripropeptin group antibiotic produced by Lysobacter sp. BMK333-48F3. J Antibiot (Tokyo) 57, 394-399.

Islam, M. T., Hashidoko, Y., Deora, A., Ito, T. \& Tahara, S. (2005), Suppression of damping-off disease in host plants by the rhizoplane bacterium Lysobacter sp. strain SB-K88 is linked to plant colonization and antibiosis against soilborne Peronosporomycetes. Appl Environ Microbiol 71, 3786-3796.

Kato, A., Nakaya, S., Kokubo, N., Aiba, Y., Ohashi, Y. \& Hirata, H. (1998). A new anti-MRSA antibiotic complex, WAP-8294A. J Antibiot (Tokyo) 51, 929-935.

Khan, A. A., Wang, R. F., Cao, W. W., Franklin, W. \& Cerniglia, C. E. (1996). Reclassification of a polycyclic aromatic hydrocarbonmetabolizing bacterium, Beijerinckia sp. strain B1, as Sphingomonas yanoikuyae by fatty acid analysis, protein pattern analysis, DNA-DNA hybridization, and $16 \mathrm{~S}$ ribosomal DNA sequencing. Int J Syst Bacteriol 46, 466-469.

Kilic-Ekici, O. \& Yuen, G. Y. (2003). Induced resistance as a mechanism of biological control by Lysobacter enzymogenes strain C3. Biol Control 93, 1103-1110.
Kimura, M. (1983). The Neutral Theory of Molecular Evolution. Cambridge: Cambridge University Press.

Kumar, S., Tamura, K. \& Nei, M. (2004). MEGA3: integrated software for molecular evolutionary genetics analysis and sequence alignment. Brief Bioinform 5, 150-163.

Lane, D. J. (1991). 16S/23S rRNA sequencing. In Nucleic Acid Techniques in Bacterial Systematics, pp. 115-175. Edited by E. Stackebrandt \& M. Goodfellow. Chichester: Wiley.

Lechevalier, M. P., De Bièvre, C. \& Lechevalier, H. A. (1977). Chemotaxonomy of aerobic actinomycetes: phospholipid composition. Biochem Syst Ecol 5, 249-260.

Lee, J. W., Im, W.-T., Kim, M. K. \& Yang, D.-C. (2006). Lysobacter koreensis sp. nov., isolated from a ginseng field. Int J Syst Evol Microbiol 56, 231-235.

Lim, J. M., Jeon, C. O., Park, D. J., Kim, H. R., Yoon, B. J. \& Kim, C. J. (2005). Pontibacillus marinus sp. nov., a moderately halophilic bacterium from a solar saltern, and emended description of the genus Pontibacillus. Int J Syst Evol Microbiol 55, 1027-1031.

Mesbah, M., Premachandran, U. \& Whitman, W. B. (1989). Precise measurement of the $\mathrm{G}+\mathrm{C}$ content of deoxyribonucleic acid by highperformance liquid chromatography. Int J Syst Bacteriol 39, 159-167.

Nakayama, T., Homma, Y., Hashidoko, Y., Mizutani, J. \& Tahara, S. (1999). Possible role of xanthobaccins produced by Stenotrophomonas sp. strain SB-K88 in suppression of sugar beet damping-off disease. Appl Environ Microbiol 65, 4334-4339.

Ryazanova, L. P., Stepnaya, O. A., Suzina, N. E. \& Kulaev, I. S. (2005). Antifungal action of the lytic enzyme complex from Lysobacter sp. XL1. Process Biochem 40, 557-564.

Saitou, N. \& Nei, M. (1987). The neighbor-joining method: a new method for reconstructing phylogenetic trees. Mol Biol Evol 4, 406-425.

Sambrook, J. \& Russell, D. W. (2001). Molecular Cloning: a Laboratory Manual, 3rd edn. Cold Spring Harbor, NY: Cold Spring Harbor Laboratory.

Stackebrandt, E. \& Goebel, B. M. (1994). Taxonomic note: a place for DNA-DNA reassociation and $16 \mathrm{~S}$ rRNA sequence analysis in the present species definition in bacteriology. Int J Syst Bacteriol 44, 846-849.

Stackebrandt, E., Frederiksen, W., Garrity, G. M., Grimont, P. A. D., Kämpfer, P., Maiden, M. C. J., Nesme, X., Rosselló-Mora, R., Swings, J. $\&$ other authors (2002). Report of the ad hoc committee for the reevaluation of the species definition in bacteriology. Int J Syst Evol Microbiol 52, 1043-1047.

Thompson, J. D., Gibson, T. J., Plewniak, F., Jeanmougin, F. \& Higgins, D. G. (1997). The CLUSTAL_X Windows interface: flexible strategies for multiple sequence alignment aided by quality analysis tools. Nucleic Acids Res 25, 4876-4882.

Tindall, B. J. (1990). Lipid composition of Halobacterium lacusprofundi. FEMS Microbiol Lett 66, 199-202.

Wayne, L. G., Brenner, D. J., Colwell, R. R., Grimont, P. A. D., Kandler, O., Krichevsky, M. I., Moore, L. H., Moore, W. E. C., Murray, R. G. E. \& other authors (1987). International Committee on Systematic Bacteriology. Report of the ad hoc committee on reconciliation of approaches to bacterial systematics. Int J Syst Bacteriol 37, 463-464.

Weon, H.-Y., Kim, B.-Y., Baek, Y.-K., Yoo, S.-H., Kwon, S.-W., Stackebrandt, E. \& Go, S.-J. (2006). Two novel species, Lysobacter daejeonensis sp. nov. and Lysobacter yangpyeongensis sp. nov., isolated from Korean greenhouse soils. Int J Syst Evol Microbiol 56, 947-951.

Yassin, A. F., Chen, W. M., Hupfer, H., Siering, C., Kroppenstedt, R. M., Arun, A. B., Lai, W. A., Shen, F. T., Rekha, P. D. \& Young, C. C. (2007). Lysobacter defluvii sp. nov., isolated from municipal solid waste. Int J Syst Evol Microbiol 57, 1131-1136. 